\title{
Prescribed-Fire Safety
}

$\mathrm{T}$ he summer, 1995 issue of REMN contained two articles that included photographs depicting restorationists conducting prescribed fires without safety equipment.

As a restorationist who has been conducting and supervising prescribed fires for more than 18 years, I have long been concerned about the casual way many restorationists approach this potentially dangerous aspect of restoration.

I am aware that restoration is different in many ways from wildland fire management, and that restorationists often conduct prescribed fires on a small scale, often informally, or even in a spirit of celebration. This, however, is no reason for neglecting basic safety equipment and procedures. Prescribed fires, even when conducted under carefully controlled conditions, are dangerous and have caused serious accidents including deaths. These accidents don't just happen on big fires out West, either. They happen on small prescribed fires, too. For decades the wildland fire community has analyzed common denominators and factors involved with fatal and near-fatal accidents. Fires on light, flashy fuels (such as prairie grasses) and smaller fires are often involved.

Here is one place where I think restorationists have something to learn from the wildland fire-control community. Organizations in wildfire control have accepted standards for personal protective equipment (PPE) on wildland or prescribed fires. These include NOMEX or other flame-retardant clothing, hard hat, goggles, gloves, and a fire shelter. A useful example is a set of guidelines recently published by the National Fire Protection Association as Standard \#1977, "Personal Protective Equipment for Wildland Firefighters." Many natural-areas organizations, such as the Nature Conservancy, and agencies such as the U.S. Fish \& Wildlife Service, the Forest Service, the National Park Service and numerous state, county and local park districts have adopted PPE guidelines for prescribed burns, many of which are considerably more demanding than the NFPA 1977 standard.

Besides the obvious value of safety for its own sake, there is another reason to take PPE guidelines seriously on restoration prescribed fires-public education.

Unlike most wildland fires, restoration prescribed fires are often conducted in or near population centers. They are conspicuous, and often attract a lot of attention. The way they are conducted conveys information to a wide and varied audience. Photos and material published in a respected national journal such as REMN will also convey similar messages.

The question is, what messages do we wish to communicate?

I would like to suggest that restoration-oriented organizations such as the Society for Ecological Restoration adopt PPE and other guidelines for prescribed fires, and also that REMN take these into account when publishing photos or other material related to prescribed fires.

I am aware that many restorationists feel that these measures are unnecessary, and that the additional expense associated with them will add an unreasonable burden to already limited budgets.

This, however, is false economy. In your editorial on "Good Restoration" in last summer's issue you noted that "especially dramatic" phases of the restoration process should be "properly ritualized." I submit that the ritual of burning should include getting in costume for the event. In the long run it will pay.
Bob Stanton
Prescribed Fire Consulting
3605 Spring Road
Oakbrook, IL 60521
(708) 323-6359 